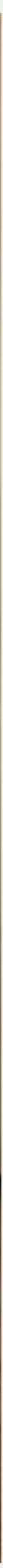

Paňcabuddha Caryā performance by the Faculty of Dance, Sirjana College of Fine Arts, September, 2018. 


\title{
PAŇCABUDDHA PERCEPTION OF CARYĀ
}

\section{ARUN SHRESTHA}

\begin{abstract}
My study of ahorātrapadasādhavidhi is the study of carya repertoire and in this repertoire of caryā of 'performing ritual', paňcabuddha is the store house of vajrayanna philosophical system from which emerges the bunch of deities who fill the kaleidoscopic scenario of visualization process in the religious practice of vajrayanna religion. The play of symbolism is swung to the extremes of space and beyond through the projection of akşobhya, vairocana, amitäbha, ratnasambhava and amoghasiddhi as five divine forces or paňcabuddha representing paňcaskandha, driving all the sentient beings to their 'nonexistent existence'. On the basis of the reliance on the 'visualization' of pañcabuddha, a path to nirvanna is eased through the 'realization' of śunyata and ultimate liberation of humanity a mass.
\end{abstract}

Carya ${ }^{\mathrm{i}}$ is basically a sādhana ${ }^{\text {ii }}$ of paňcabuddha iii who in essence is paňcaskandha ${ }^{\text {iv }}$.

To authenticate the statement pronounced here, let us begin analysing the conceptual vajrayanna phenomenon like caryā, sädhana, paňcabuddha and paňcaskandha in sequence and establish a logical relationship.

Caryā in essence denotes a path for a human life leading to salvation. It endeavours to explain the deeper meaning of the existence of the human life in body and mind. In this process, for all practical purposes, practice of song, dance and the rituals are the means to enliven the spirit in man. It is scientifically religious or religiously scientific. Very uncharacteristically, it does not rely on faith or moral lessons as preaching of the religions do. The study reveals the system to be followed to lead a chartered trail to enlightenment. It's so called mystical thought process is aesthetically spiritual and thus contradictory in character inciting the human mind to solve the mystery of complex human life's existence (bhāva) and non-existence (abhāva). Apparently aesthetic Caryā or practice is inherently spiritual in content.

In caryā one dances away to nirvāña, which is liberation from future rebirths realizing the extinction of sufferings, in the ritual process or sädhana, whereby worshiper becomes worshiped and achieves divinity. 


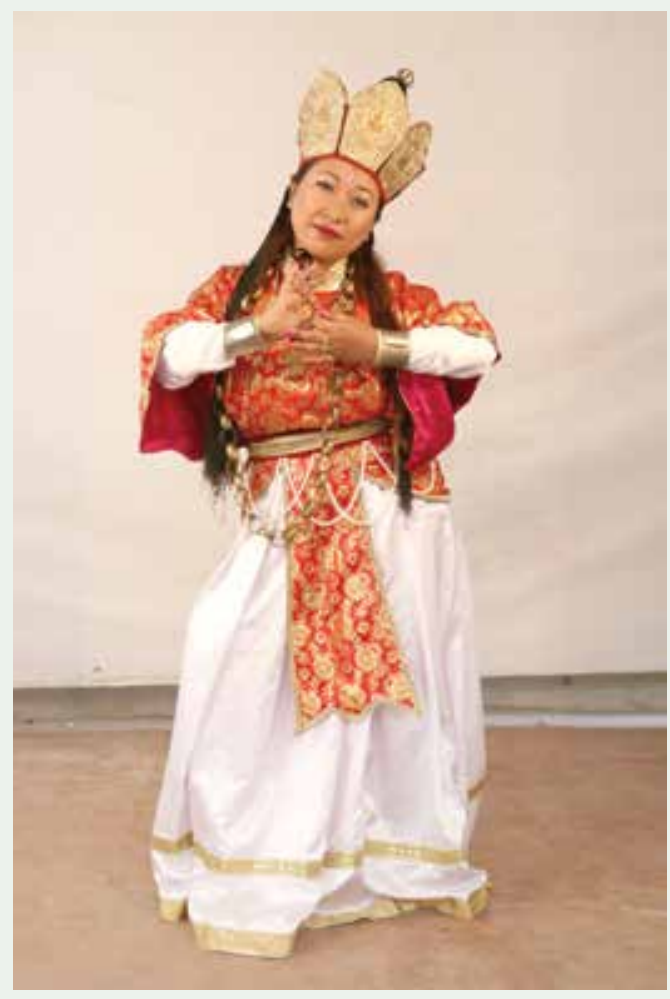

Vairocana

What then is the place of sädhana in caryā?

'The Sädhana is concerned with the process (or a caryā) for worshiping a particular deity... This consists in meditating in a quiet place and there practicing Yoga till a state similar to deep sleep is brought about. In this state of deep sleep the ascetic communes with the Infinite Spirit or the inexhaustible store-house of energy, which is supposed to be the highest creative principle behind the world structure. By this communion the ascetic draws forth energy from that inexhaustible store-house, and becomes powerful himself. This process of the realization of the Infinite Spirit is what is called sādhana. The deity is the part of this psychic

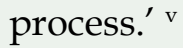

This caryā or practice of a sādhana or process is in fact a yoga or rather a şađaňga yoga adhered to in vajrayāna Buddhism which affiliates itself to the concept of paňcabuddha in execution of yoga practice.

This is how guhyasamäjatantra explains the relationship of şađaňga yoga with paňcabuddha: vi

Caryā is a yoga and in vajrayāna yoga of six limbs, şađaňga yoga, are employed: pratyahāra, dhyāna, prāñāyāma, dhāraña, anusmŗti and samādhi.

Pratyahara is the process by which the ten sense-organs are controlled.

Dhyanna is the conception of the five desired objects through paňcabuddha.

Prānāyama is the control of the breathing process by which breath is drawn from inside and is meditated upon.

Dhäranga is the meditation of one's own mantra.

Anusmrsti is the constant meditation of the object for which the psychic exercise is undertaken.

And finally, when by this process the 


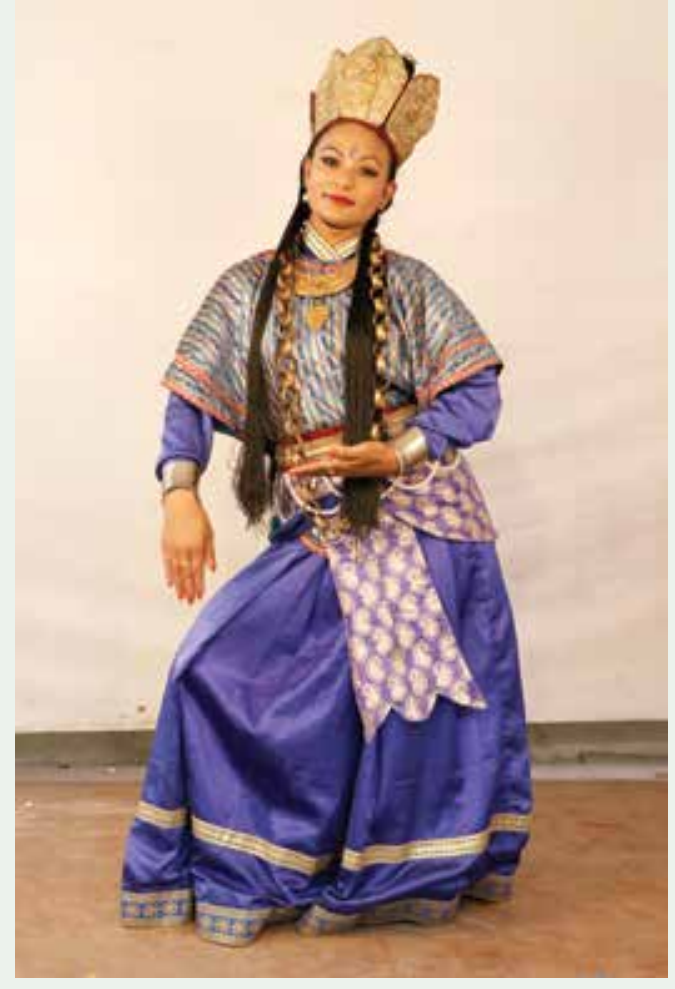

Akşobhya

transcendental knowledge is suddenly realized by the worshiper, it is known as samādhi. vii

In a yoga process, dhyāna (meditation) is the conception of the five desired objects through paňcabuddha, the five Buddhas, which is again sub-divided into five kinds: vitarka (cogitation), vicāra (thinking), priti (pleasure), sukha (happiness), and ekāgratā (concentration). viii

The five desires are in condensation through the application to the five Buddhas. Meditation (dhyanna) is said to be imagination. And that Meditation is fivefold: Primary
Conception (vitarka) is the secret triad, from the enjoyment of which comes Secondary Conception (vicāra). The vicinity of joy is the third, and the sum of pleasure is the fourth. One's own consciousness with removal of the upsurge of knowledge and knowable, is known as the fifth, with a peace composed of all Buddha and abiding in all desires. Drawing forth the breath made of five knowledge and which is the self-existence of the five elements, one should imagine it in the form of a tiny ball on tip of the lotus nose. ${ }^{\text {ix }}$

In a caryāgìti of caryāgìtikoşa, paňcabuddha is assigned a role of a karnadhāra or helmsman in the sādhana or process of caryā or religious practice: ${ }^{x}$

By using three, (kāya, vāka and citta) as a protection, kill (by) the group of eight

Honor compassion and void (in your) own innate body

Cross the worldly existence, as the ocean of water, like a dream of illusion

Think of (worldly existence) in the middle of the confluence of the rivers made of waves

By the means of Pañca Tathāgata as a large oar used as rudder or helm The outer body, Kŗşna (says), is a web of illusion

Smell, touch and taste are such, as resembling a dream forsaken of (or without) sleep 


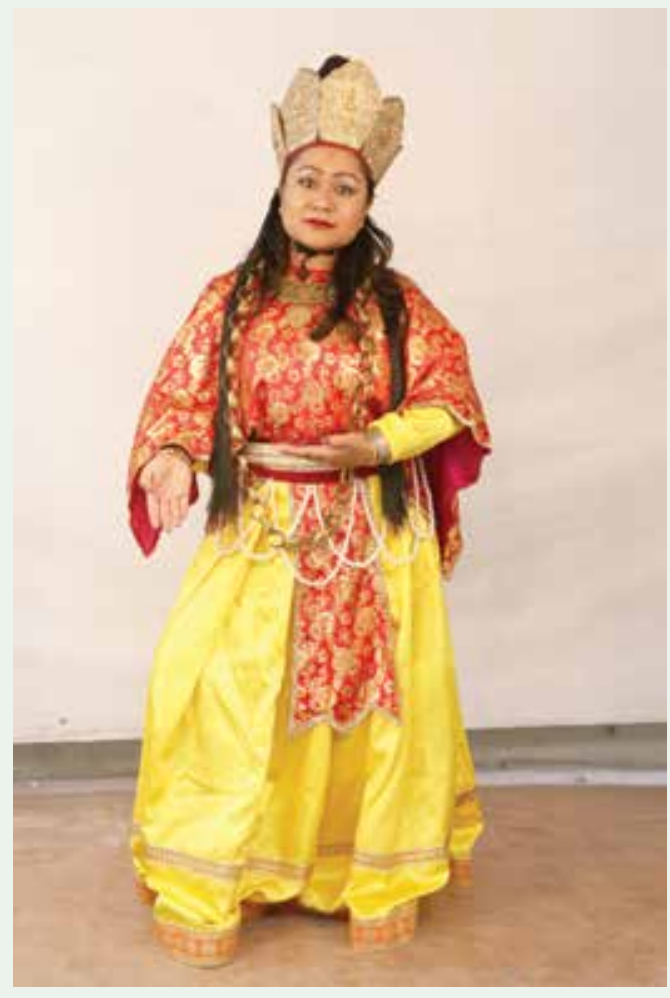

Ratnasambhava

Perception (citta) is a helmsman for a path to void

Krşñā (the composer) departs in addiction (or devotion) of the great pleasure or bliss (mahāsukha)

After establishing a link between caryā, sādhana and paňcabuddha, we are led to a further link of these three to paňcaskandha. Guhyasamājatantra very categorically specifies paňcabuddha to be nothing but paňcaskandha or basic elements human beings are composed of:

pancaskandhā samasena pancabuddhāh prakīrtitāh $l$

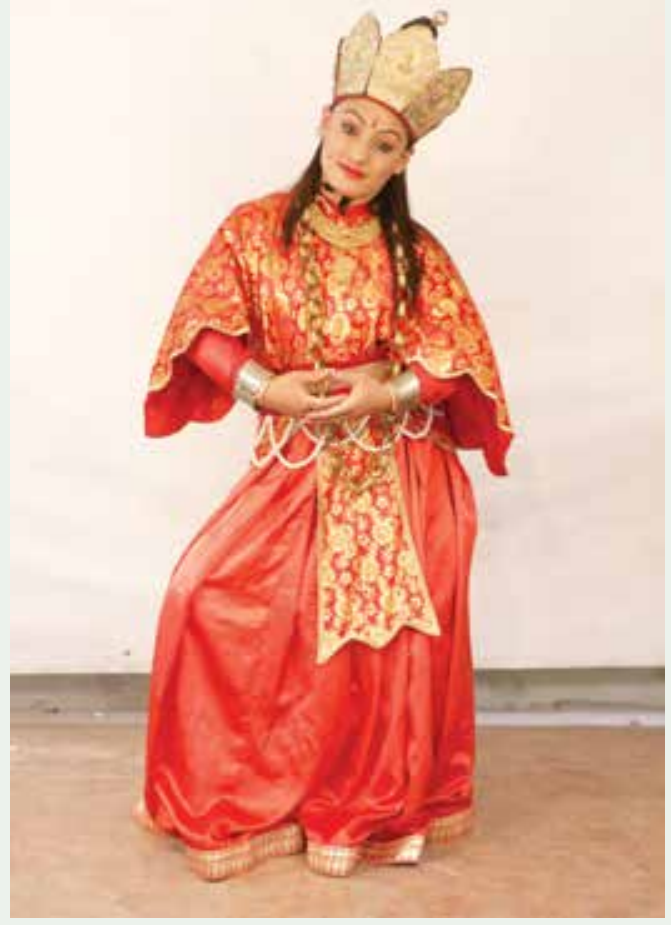

Amitābha

vajra-āyatanānyeva

bodhisatvāgryamañđalamiti $l l 50 \mathrm{ll}$ guhyasamājatantra saptadasa pațalah p.111

The five skandha or paňcaskandha are proclaimed in short to be the five Buddha or paňcabuddha.

In a dramatic turn of vajrayāna thought process, vajrayāna caryāgìti incites us to destroy the basic elements of our constituent that is paňcaskandha, on a spiritual path to elevate and achieve nirvana: xii

The mind is full of the void by the grace of sahaja. 


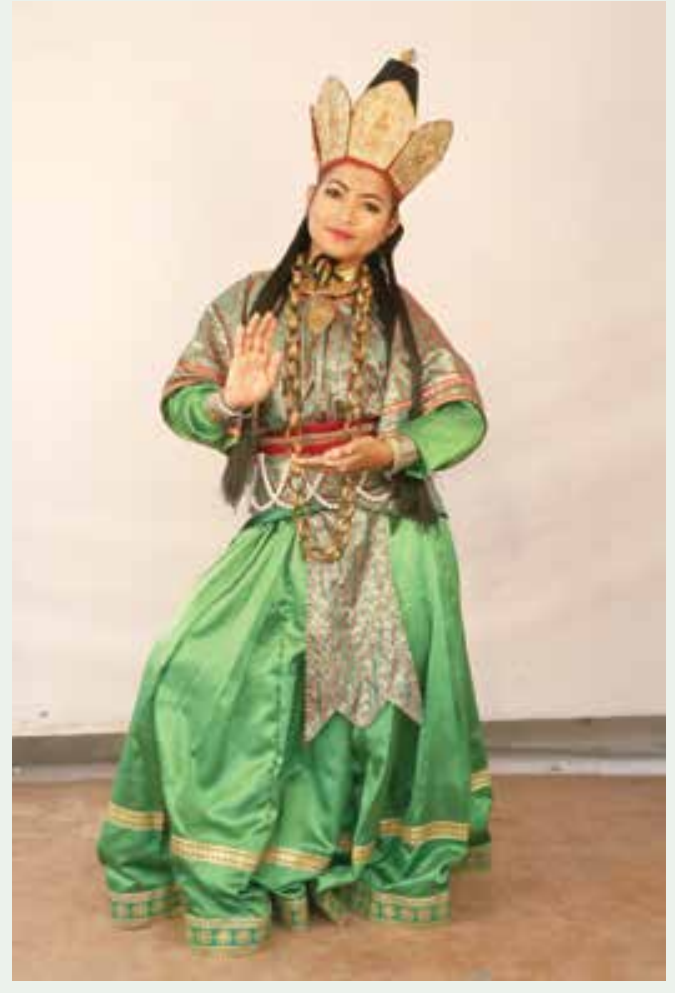

Amoghasiddhi

Do not be sorry for the loss of the skandhas.2

Tell, how Kāhna does not exist.

He is flourishing every day, entering into the three worlds. 4

The fool is sad to see the sense of destruction.

Do the broken waves suck the ocean?6

The fool cannot see the existing man.

The butter seen contained in milk is not seen. 8

Nobody goes or comes in this world.

In this style the yogin Kähna makes sport.10 xiii

Vajrayāna Buddhism accepts the basic doctrine of existence and nirvanna. The reality of the existence of the body and mind apart, it vies to perfect the mundane existence through the yogic exercise to reach the ultimate goal of śunyatā passing the stage of sahaja. Identifying 'the five mundane existence' in paňcaskandha symbolized by paňcabuddha, it aims to perfect, control and ultimately destroy those panca skandhas, of which pañcabuddha is a manifestation, which signifies 'so-called existence' to attain nirvānga conceptualized in the form of sunnyatā. Sahaja, in this process, is the state of the mind.

In this backdrop of the conceptual formation of the doctrine, leaning on belief, faith and soul is not called for. Pure reasoning is applied in explaining the emmundane existence' and final relief from it all, so the need to fall back on faith is negated. When the reality of the emmundane existence' is denied the belief in the existence of the soul takes a back seat, and so the concept of re-birth.

In the kaleidoscopic formatting of vajrayāna Buddhism religious practice, a visual form given to paňcabuddha is a visualization part and the concept of paňcaskandha attached to it is a part of the realization path.

Closing the statement we began with, we can assertively pronounce that 'caryā is a sädhana of paňcabuddha who in essence is nothing but paňcaskandha' destined to be won over in a spiritual 


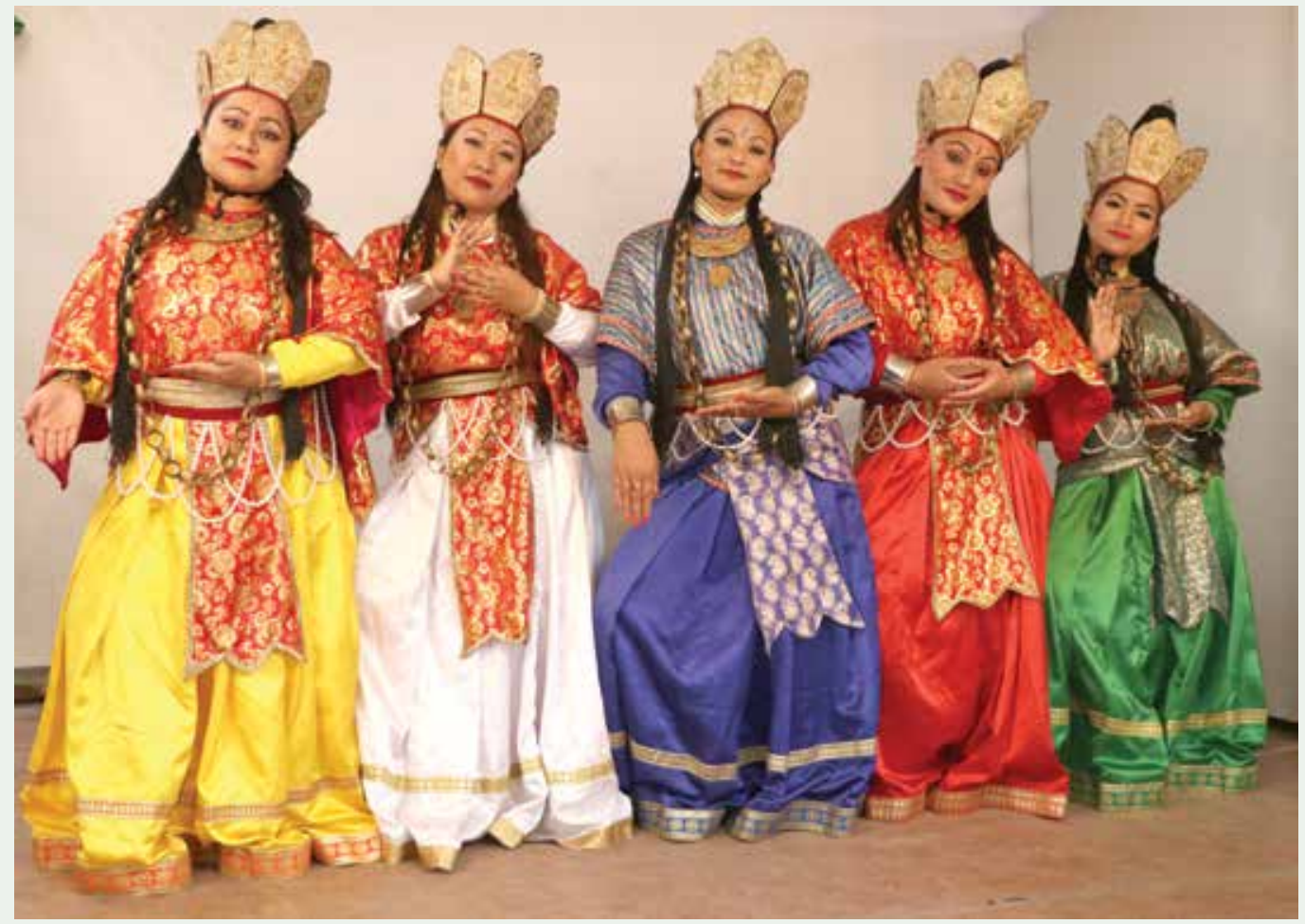

Paňcabuddha

path of vajrayāna Buddhism so conceptualized.

On a parting note, let us praise the gains of caryā: xiv

One captures all the mystical powers and shines in the cosmos even when vanishing from sight.

One sees with divine eyes when set on trivajra abode of kāya, vāka and citta.

One hears all the sounds through magical psychic power.

Through a drama or nātaka one knows kāya, vāka and citta of all the sentient beings.

One remembers the incidents of the eon of the former lives dwelt in samsāra as if only of three days. 


\section{References}

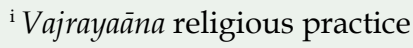

ii the process of excessive concentration or focus for evocation

iii akśobhya, amitäbha, amoghasiddhi, vairocana and ratnasambhava

iv rūpa, vedanā, saňgyā, saňskāra and vigyāna

v Buddhist Iconography by Binoytosh Bhattacharya p. 24

vi aşānāmindriyāñāntu svavrtisthānāntu sarvatah 1

pratyāhāramiti proktamāhāra pratipattaye 1114111

pancakāmāh samāsena pancabuddhaprayogatah 1

kalpanam dhyānamucyate taddhyānam pancaddhā bhavetall 14211

vitarka ca vicāram ca prìtiśaiva sukham tathā 1

cittasyaikāgratā caiva pancaite dhyānasangrahāh 1114311

guhyatantrşu sarveşu vividhāh parikīrtitāh 1

guhyam tarkodayam tarkam vicāram tat prayogatah 1114411

tritìyam prïisankāśam caturtham sukhasangeaham 1

svacittam pancam gyeyam gyānam gyeyo dayaksamam 1114511

sarvabuddhamayam śāntam sarvakāmapratişthitam 1

pancagyānamayam śvāsam vi pancabhūtasvabhāvakam 1114611

niśvārya pinđarupeña nāsikāgre tu kalpaye 1

pancavarņam mahāratnam prāyāyāmamiti smŗtam $11147 \mathrm{ll}$

svamantram hṛdaye ghyātvā prāngabindugatam nyaset 1

nirudhya cendriyam ratnam dhārayan dhārañā smŗtam 1114811

nirodhavajragate cite nimittamupajāyate 1

pancaddhātu nimitm tat bodhivajreņa bhāşitamll 14911

prathamam marīikākāram dhūmrākāram dvitīyaam 1

trotīyam khaddhotākāram ${ }^{\text {vi }}$ caturtham dīpavajjolam 1115011

pancam tu sadālokam nirabhram vi gaganasannibhm 1

sthirantu vajramārgeņasphārayìta khadhātuşu 1115111

vibhāvya yadanuamŗtyām tadākārantu sansmaret 1

anusŗtiriti geyāpratibhāsohtra jāyate 111521

pragyopāyasamāpatyā sarvabhāvān samāstah 1

samhr̆ta piņđayogena bimbamadhye vibhāvaam 1115311

jhațiti gyānanişpattih samādhiriti saggyitah 1 
pratyāhāram samāsāddha sarvamantrairadhişthyate 1115411

guhyasamājatantra aşțādasah pațalah p.132-133

vii Buddhist Iconography by Binoytosh Bhattacharyya p.25-27

viii Buddhist Iconography by Binoytosh Bhattacharyya p.25-27

ix Yoga of Guhyasamājatantra by Allex Wayman p.45

${ }^{x}$ sanskrta cāryā gìti of caryāgìtikoşah 13

trisarananauka krtva astakam hatam 1

nijadeha karunasunyate mahile $111 \mathrm{ll}$

tirnau bhavajaladhih yatha krtva mayasvapnam 1

madhyevenim tarango maya matah (=gyatah) 11

pancatathagatam krtva kenipatam 1

vahya kayam krsna mayajalam 11211

gandhasparsarasa yadrsastadrsah 1

nidravihine svapnasadrsah 11311

cittam karnadharah sunyatamarge

gatah krsno mahasukhaprasange 11411

Caryāgìtikoşa of Buddhist Siddhas by Prabodha Chandra Bagchi

xi Yoga of Guhyasamājatantra by Alex Wayman p.229

xii 114211

[ rāgakāmoda xii kānhapādānām 1 ]

cia sahaje śūna sampunnā 1

kāndhavitoen mā hohi visannā ll [1] 11

bhanga kaise kānha nāhi 1

pharaha anidinam ${ }^{\text {xi }}$ teloe pamāe 11 dhruvapada 11

mū d'ā ditha ${ }^{\text {xii }}$ nàtha dekhi kāara 1

bhānga taranga ki soşai sāara ll [2] dhru ll

mūd'ā acchante loa na pekhai 1

dudha mājhe lađa xii ņacchante dekhai 11 [3] dhru 11

bhava jāi ña àvai ņa ethu koha 1

aisa ${ }^{\text {xi }}$ bhāve vilasai kānhila joi 11 [4] dhrull 11

DohāKośaCaryāGīti No. 42 by Nilratna Sen

xiii Dohā Kośa Caryā Gìti No. 42

Translation by Nilratna Sen Appendix-A p.143 Caryāgìtikośa 
xiv Gains from caryā:

antarddhāneşu saveşu sāhastraikāvabhāsakah 1

harate sarvasiddhīnām bhunkte kanyām surāgrajām 115311

gangāvālukasamān buddhāmstrivajrālayasansthitān 1

paśyate cakşurvajreņa svahastaikamyathāmalam 115411

gangāvālukasamaih kşetraih ye śabdāh samprakìrtitāh 1

śrņotyabhigyāvaśatah śrotrasthabhiva sarvatah $1155 \mathrm{ll}$

gangāvālukasamaih kşetraih kāyavākcittalakşaņam 1

sa vetti sarvasatvānām cittākhyam nāțakodbhavam 115611

gangāvākasamaih kalpaih sansārasthitisambhavam 1

purvanivāsasamayam dinatrayamiva smaret $1157 \mathrm{ll}$

guhyasamājatantra samaya sādhanāgranirdeśapațalo dvādaśah p.45

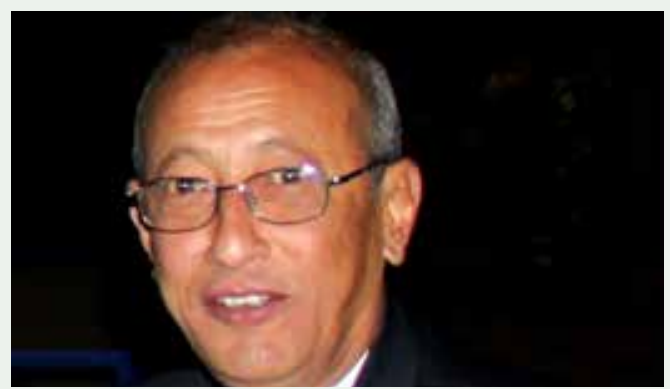

\section{Arun Shrestha}

Born April 24, 1947, with schooling and initial college years from Mumbai, Maharashtra Board and Bombay University, graduated from T.U. Kathmandu in Economics and English Literature.

Career spanned as a management personnel (Director/GM/MD) in the private sector of handicraft house (Kathmandu Travels), airlines (Nepal Airways), ground water management (NEDRILL) and consultancy (USAID) with addition of a contribution as a training and assistance personnel to Election Commission and Ministry of Tourism.

Two papers presented on Caryā and Caryānrrtya on the auspices of Department of Education and Sanskritik Sansthan, Kathmandu, Nepal.

Caryā: Dancing Away to Nirvānāa, a book based on study of 'Ahorātra Pada Sädhana Vidhi' ready for publication. 